\title{
EARLY LIFE HISTORY OF THE DEEP- SEA SMELT, GLOSSANODON SEMIFASCIATUS (KISHINOUYE) (TELEOSTEI : CLUPEIDA) PART I
}

\section{$\operatorname{AUTHOR}(\mathrm{S})$ :}

Nishimura, Saburo

\section{CITATION:}

Nishimura, Saburo. EARLY LIFE HISTORY OF THE DEEP-SEA SMELT, GLOSSANODON SEMIFASCIATUS (KISHINOUYE) (TELEOSTEI : CLUPEIDA) PART I. PUBLICATIONS OF THE SETO MARINE BIOLOGICAL LABORATORY 1966, 13(5): 349-360

\section{ISSUE DATE:}

1966-02-25

URL:

http://hdl.handle.net/2433/175419

RIGHT: 


\title{
EARLY LIFE HISTORY OF THE DEEP-SEA SMELT, GLOSSANODON SEMIFASCIATUS (KISHINOUYE) (TELEOSTEI : CLUPEIDA) PART I ${ }^{1 \text { ) }}$
}

\author{
Saburo NISHIMURA \\ Seto Marine Biological Laboratory, Sirahama
}

With Plates XIII-XIV

According to the recent revision by Cohen (1958) of the fishes of the subfamily Argentininae (Teleostei : Clupeida) of the world, three species of them are known from the Japanese and adjacent waters. Of these, the deepsea smelt, Glossanodon semifasciatus (KISHINOUYE), is most familiar to the Japanese people, being called by them "nigisu" that means a Sillago-like fish in Japanese. It is distributed around the edge or on the slope of the continental shelf along the southern half of Japan and the southeastern part of Korea, and is caught in a large quantity by trawl-fishery, especially abundantly in the southeastern Japan Sea and off the Pacific coasts of middle Honshu and Shikoku. Nevertheless, relatively few informations are available concerning this economically important fish ; published literatures concern chiefly taxonomic, morphometric or some biological features of the adult fish (MATSUBARA 1943 ; Kamohara 1952 ; Ochiai 1952a, 1952b, 1954 ; Hany 1956 ; Watanabe 1956 ; CoHen 1958 ; etc.), while nothing is kown of the early phase of its life history. This presents a striking contrast to the situation among its allied species in the North Atlantic, Glossanodon leioglossus (VALEnCIEnNes), Argentina silus (Ascanius) and A. sphyraena L., the early life history of all of which has been clarified since long ago (Schmidt 1906, 1918; Ehrenbaum 1909; Fage 1910; SANzo 1931 ; Karlovac 1949 ; etc.)

In these ten years, while engaged in examination of the plankton samples collected in the Japan Sea, I have been aware that the eggs and larvae of an unknown fish, with a quite characteristic appearance, occur not infrequently in the samples. Consulting the descriptions of the early development of the Atlantic argentines given by the above-named European authors and further comparing the meristic characters of the postlarvae, collected often simultaneously and probably belonging to the same fish which gives birth to the

1) Contributions from the Seto Marine Biological Laboratory, No. 444.

Publ. Seto Mar. Biol. Lab., XIII (5), 349-360, 1966. (Article 18) 
eggs and larvae in question, with those of the adult Glossanodon semifasciatus, I was soon convinced that I was treating nothing but embryonic and larval forms of this Japanese argentine species.

In 1962 to 1963, when I was a member of the staff at the Japan Sea Regional Fisheries Research Laboratory in Niigata, I had a chance to participate in the program of the biological and hydrographical investigations of the Sado Straits planned by the laboratory. During the operations made following the program, many specimens of the deep-sea smelt in the developmental stages succeeding the metamorphosis were caught by a beam-trawl, and this enabled me to trace the development of this fish to its advanced young stage.

In this paper is described the early development of this argentine fish clarified on the above-mentioned material and are also presented some discussions on the distributional pattern of the eggs of this fish in the sea and on certain biological features of its larval to young stages.

I am grateful to Dr. Sukekata Ito and Mr. Shôgo KaSAHARA of the Japan Sea Regional Fisheries Research Laboratory for their kind advices and help in sorting a portion of the plankton samples, and to Messrs. Akira Ouchi ${ }^{2}$, Muneo Okiyama and Kôsuke Naganuma of the same laboratory for their cooperation during the works in the Sado Straits. The manuscript was read by Prof. Huzio Uxinomi and Dr. Takasi Tokioka of the Seto Marine Biological Laboratory, to whom I wish to extend my sincere appreciation.

\section{Material and Methods}

The eggs, larvae and postlarvae of Glossanodon semifasciatus were picked out of the plankton samples taken in the eastern Japan Sea by a conical net, $45 \mathrm{~cm}$ in mouth diameter and stretched with the gauze with meshes $0.3 \times 0.3$ $\mathrm{mm}^{2}$, being vertically hauled from $150 \mathrm{~m}$, or from just above the sea floor at the shallower stations, to the surface. The specimens in the metamorphic or young stage were collected by towing a small beam-trawl, $3 \mathrm{~m}$ in mouth width and $4 \times 4 \mathrm{~mm}^{2}$ in mesh size of the net at the cod end, on the 100 to $120 \mathrm{~m}$ bottom in the Sado Straits off Niigata. Some specimens of further later developmental stages were picked out of the commercial catches made by the motor-trawlers and landed at the Nigata fish market. The specimens were all immediately preserved in formalin, and later processes were all made in the laboratory.

Measurements and drawings of the eggs and the fishes of larval to young stages were made by using an ocular micrometer set to the dissecting microscope and under lower magnification from $\times 15$ to $\times 60$. Some specimens were

2) His present address is Kumamoto Prefectural Fisheries Experimental Station, Hondo-Shi, Kumamoto-Ken. 
examined after they were made transparent in glycerin. Measurements of the larger specimens were made by using dividers and a $30-\mathrm{cm}$ rule.

\section{Early Development}

Embryonic Stages (Pl. XIII, Figs. 1 to 3 )

The eggs are mostly spherical, 1.5 to $1.6 \mathrm{~mm}$ in diameter in preserved specimens; sometimes they assume a slightly ovate form but in such a case the greater axis never exceeds 1.05 times of the lesser axis. The egg membrane is thin, colorless and transparent; it is smooth and without any special structures on the outer surface but a rough appearance studded with fine granules and furnished with wrinkles all over the inner surface ${ }^{3}$. No iridescence is observed. The perivitelline space is rather narrow in the preserved specimen. The yolk is segmented. There is a single oil globule, about $0.36 \mathrm{~mm}$ in diameter. Pigments are observable neither on the embryo nor on the yolk sac before the early tail-bud stage (Fig. 2), when some melanophores appear on the lateral side of the trunk in the region containing the anterior 17 or 18 myomeres and in addition some melanophores, often stellate in form, on the dorsal surface of the yolk sac adjoining to those pigmented myomeres, and furthermore minute dark brown pigment cells are formed on the dorso-lateral corner of the tail bud in the region including the posterior 15 or 16 myomeres, mostly concentrated in several blotches on each side of the zone where the top of myomeres meets the nerve cord. By this stage, the oil globule has become to occupy the posterior position in the yolk, just beneath the myomere XXXII or XXXIII. The myomeres count 45 in the specimen shown in Fig. 2. Eyes are superficially well developed, but without any pigments. There is a nasal plate just in front of the eye. Cerebral lobation is clearly visible: large midbrain (mesencephalon) together with indistinctly-defined forebrain (telen- + diencephalon) is differentiated from hindbrain (meten- + myelencephalon) by a sharp constriction ; metencephalon or cerebellum is developed only weakly as yet. Auditory vesicle is formed considerably posterior to hindbrain. Heart is seen suspended from the dorsal surface of the body cavity at the site of metencephalon. Rudimentary finfold encircles the embryonal body along the dorso-median edge from about the myomere VI to the tip of the tail and on the free midventral edge.

In an advanced tail stage shown in Fig. 3, the embryo is further developed with the tail wrapping around the side of the yolk sac and the head. A remarkable fin-fold, nearly as broad as the depth of the body, frills the embryonal body along the dorso-median edge posterior to the myomere $\mathrm{V}$

3) It is not impossible that these structures on the inner surface of the membrane are nothing but artifacts at fixation. 
and along the entire free midventral edge. Melanophores are distributed on the body in four vaguely defined blotches: the first is a horizontal, very thin bar situated at the level of the lower edge of the myomeres just in front of the beginning point of the ventral fin-fold; the second is again a horizontal but more massive bar along the dorso-lateral corner of the body cavity approximately at the middle of the distance from the anterior pigment blotch to the posterior end of the body cavity; the third is a very massive blotch of pigment cells situated along the dorso-lateral surface of the posterior part of the body cavity; and the last pigment blotch is found on the fin-fold just above and beneath the myomeres near the tip of the tail. Highly branched melanophores are also distributed on the dorsal surface of the yolk sac along the trunk region between the first and the second blotch of somatic melanophores. The myomeres count $34+\mathbf{1 1}=45$ in the specimen shown in Fig. 3 . No pigment on the eye; a single choroidal fissure on the antero-inferior margin of the eye. Nostrils are represented by simple, oval depressions. The head is still rather flat, though the brain has now fairly developed, especially the optic lobes of the mesencephalon are swollen and a marked ventrad flexure (=pontic flexure) is developed between the metencephalon and myelencephalon. The epidermis along the dorso-median line of the body from the snout to just before the beginning point of the dorsal fin-fold is furnished with aggregations of many glandular structures containing highly refractive substance, which appear to be the hatching glands, since they are not observable on the embryos prior to the late tail stage and disappear completely on the larvae hatched out.

\section{Early Larval Stage (P1. XIII, Fig. 4)}

The larva just hatched out is estimated about $4 \mathrm{~mm}$ long to the tip of notochord and is still provided with a considerably large yolk sac. The dorsal fin-fold reaches almost the hindbrain. The rudiment of pectoral fin is found as an isolated mass of myoblasts at the site where the lower edge of the myomeres V and VI meets the yolk sac. The head is roundish, short and high; the snout is blunt. The mouth is not yet formed at all. The brain is further developed: the optic lobes are now much swollen, the pontic flexure is very noticeable, and the median furrow between the right and left lobes of the hindbrain is very conspicuous. In accordance with the cerebral development, the anterior unsegmented portion of the trunk is shortened and the auditory vesicle is shifted a little more anteriorly than in the embryonal stage. Faint lobations are observable on the eye which lacks pigment completely as yet. In the specimen shown in Fig. 4 , the myomeres count $34+13$ $=47$; this number is near that of vertebrae in the adult stage (mainly 46 to 49 with the mode at 48 , excluding the urostyle: Watanabe 1956). The body, exclusive of fin-fold, is deepest near the middle of the body. The pigmenta tion is essentially the same as in the last embryonic stage. 
The early larva depicted in Fig. 4 is 3.9 to the tip of the notochord; eye diameter 0.27 ; snout to the base of pectoral rudiment 1.03 ; preanus length 2.67 ; postanus length 1.25 ; greatest body depth 0.24 ; all in $\mathrm{mm}$.

\section{Advanced Larval Stage (P1. XIII, Fig. 5)}

The body is quite slender. Upper and lower jaws are formed, but still rather weak. Gill-cleft is opened. Four pairs of gill-bars are also formed, but wholly devoid of gill-filaments. The pectoral fin is definitely developed, though still of a much smaller size than in the more advanced stages; it is situated at the intersept of myomeres II and III. On the brain, the olfactory lobes are differentiating from the optic lobes, and the saccus dorsalis and the epiphysis are clearly observed. Pigments have appeared on the eye, and the lobation on the iris is most conspicuous throughout the developmental stages. The auditory vesicle is very large and reaches just hehind the eye. The rudiment of liver is being formed. The anus opens far backward, at about three quarters of the body length from the snout. The body is deepest at about the middle of the preanus length. Some melanophore blotches appear on the head: on the tips of the snout and lower jaw, along the lower lateral edges of the lower jaw, and on the outer and inner surfaces of the opercular flap postero-inferior to the eye. There are also conspicuous melanophore blotches distributed along the sides of the rudiment of ethmoid cartilage, from the anterior margin of the eye to near the tip of the snout passing below the bottom of nasal depressions; the main concentration is found just anterior to the eye. Thin, branched melanophores are diffused on the surface of the yolk sac. The black pigments on the body surface are now arranged in five, much more clearly defined and regularly distributed blotches: the first blotch is situated around the base of the pectoral fin, the second on the lower lateral and ventral surfaces of the myomeres XIV and XV and further extending down along the lateral plate to cover the dorsal part of the adjoining gut region, the third on the lower lateral and ventral surfaces of the myomere XXIV, the fourth is the largest and situated on the same surfaces of the myomeres XXX to XXXV and extending along the lateral plate covering the dorsal surface of the gut posteriorly to near the anus, and the last on the basal part of the fin-fold surrounding the tip of the tail.

The larva illustrated in Fig. 5 is 6.7 to the posterior end of notochord; snout 0.27 ; eye 0.36 ; head 0.87 ; snout to the base of pectoral fin (=prepectoral) 1.27 ; preanus 4.97 ; postanus 1.76 ; greatest body depth 0.43 ; all in $\mathrm{mm}$. The myomeres $37+11=48$.

Postlarval Stage (Pl. XIV, Fig. 6)

The head has become somewhat slender with the elongated snout and the less elevated optic lobes, while the body has become shorter and stouter. 
The body is deepest at the middle of the distance between the pectoral base and the rudiments of the dorsal fin-rays. The snout is projected bluntly. The mouth is fairly stout. The nostril is still a single depression, though it is now of a considerable size and the aperture is gourd-shaped, longitudinally elongated and slightly constricted at the middle. The lobation on the iris is somewhat less conspicuous than in the preceding stage. Gill-filaments are being formed. The pectoral fin has become much larger; its base is roundish and the membraneous fin is broad and fan-shaped. The intestine is very stout, thick in diameter, and alreadly equipped with ring-folds (Ringfalten after JACOBSHAGEN 1937) on the inner surface-about 12 rings in the posterior part of the middle intestine and about 4 in the rectum. The rudiments of dorsal, anal and caudal fin-rays are in the process of differentiation; and the rudiment of shoulder girdle appears as a thin, vertical thread-like structure just in front of the base of the pectoral fin. There are ten, very conspicuous vertical blotches or stripes of melanophores on each side of the trunk and tail; in addition, there are minute pigment cells along the posterior margin of the pectoral fin and a few pigment blotches below and around the posterior tip of the notochord. The pigmentation on the head is similar to that in the advanced larval stage; the melanophores on the inner surface of the opercle are now arranged clearly into a horizontal bar slightly inclined, while those on the outer surface are limited to the postero-ventral corner of the opercle.

The postlarva illustrated in Fig. 6 measures 12.7 to the tip of notochord; snout 0.73 ; eye 0.67 ; head 2.24 ; prepectoral 2.72 ; preanus 10.02 ; postanus 2.72 ; greatest body depth 1.09 ; all in $\mathrm{mm}$. The myomeres $38+11=49$.

Early Metamorphic Stage (Pl. XIV, Fig. 7)

Following the view of Aboussouan (1964) and other authors, the metamorphosis or metamorphic stages are installed between the postlarval (or alecithic larval) and the young stages. The specimens in the metamorphic stages show transitional morphology from the larval to the young stages. It seems worth while to note that all of the Glossanodon specimens mentioned so far were collected from the middle layers of the sea by plankton net, but those in the metamorphic and succeeding stages were all taken by bottom trawling.

The specimen in an early phase of the metamorphic stages has a rather short and stout body, although the head has become more slender with the snout fairly elongated. The dorsal profile of the snout descends in a convex curve from the frontal region to just behind the premaxillary, and the lateral view shows that the nostril is situated well below the dorsal profile of the snout. The body is deepest immediately behind the base of the pectoral fin. Though the remnants of the larval fin-fold are still faintly visible, especially on the dorsal edge of the posterior part of body, the rays of the 
dorsal, anal, caudal and pectoral fins have been fully differentiated, their numbers attaining respectively those seen in the adult stage. The pectoral base as well as its fin are still roundish in outline and situated at a rather higher level on the lateral side of the trunk. The ventral fin is formed with the definitive number of rays. Premaxillary and maxillary are differentiated; opercular bones are also in differentiaion, not yet covering the entire gills, however. Minute, comb-like teeth are densely arranged on the inner side of the margin of the dentary in the range from near the angle of gape to the symphysis and on the similar portion of the premaxillary. No tooth on the vomer or the tongue as yet. Branchiostegal rays are formed. The nostril opens with two apertures separated by a septum, and about ten, radiallyarranged laminae are observable within the nasal depression. The iris is almost perfectly round in outline, the lobation being no longer conspicuous; and a crescent white tissue (COHEN 1958) begins to appear on the dorsal and ventral segments of the iris. The cerebellum shows a prominent development, and the gross morphology of the brain has now almost attained the adult pattern. Melanophores begin to appear in the region of the cerebellum adjoining to medulla oblongata, and on the antero-lateral region of the optic lobes. The pigmentation on the head and body is roughly similar to that found in the postlarval stage, though it is now in the most developed state throughout the life history: the flecks on the tip of the premaxillary, the tip and lower lateral margins of the dentary and on the lower edge of the articular and opercular bones are very conspicuous, and the transverse stripes on the lateral side of the trunk and tail are quite remarkable. Some melanophores are also formed at the dorsal corner of the outer surface of the opercle, along the rays of the ventral and anal fins (these pigment cells later migrate to be accumulated in the proximal portion of fin-rays) and on the edge of the anterior extension of the lower leaf of the caudal fin. The pigment blotches along the mesethmoid and on the inner surface of the opercle, on the other hand, show an indication of dwindling; moreover, the main concentration of the former is shifted anteriorly, some melanophores having migrated to the upper surface of the anterior part of the mesethmoid.

The specimen shown in Fig. 7 is 22.3 in standard length; snout 1.82 ; eye 1.58 ; head 5.75 ; prepectoral 6.29 ; snout to the base of dorsal fin (=predorsal length) 10.7 ; snout to the base of ventral fin (=preventral length) 11.6 ; snout to the base of anal fin (=preanal length) 17.6 ; preanus 17.45 ; postanus 4.85 ; greatest body depth 2.57 ; all in mm. Number of fin-rays: dorsal 12 ; anal 12 ; pectoral 20 ; ventral 11 . The myomeres $38+10=48$.

Late Metamorphic Stage (P1. XIV, Fig. 8)

The muzzle is protruded and pointed, and the body has become tapered posteriorly, thus the general outline considerably approaches the adult form. 
The dorsal profile of the snout is still convex, and the upper rim of the nostril can be seen slightly within the profile on lateral view. The greatest body depth is just behind the base of the pectoral fin. The adipose fin is clearly differentiated, and the pectoral fin has become lanceolate and its situation is lowered on the lateral side of the trunk. The comb-like teeth on the premaxillary have wholly disappeared; but those on the dentary remain still, extending all the span to the symphysis. Vomerine and tongue teeth are in the process of formation; they are pointed and bent backward like those in the adult, but the tongue teeth are situated not along but rather inside the frontal margin. The opercle is extended to cover the gill-filaments completely. The pigmentation has abruptly changed: the flecks on the tip of the snout and on the lower lateral edges of the articular and opercular bones show a trend toward dwindling and the transverse stripes on the body sides are decidedly reduced, while some new pigment blotches of a conspicuous size have appeared on certain places other than previously referred to, i.e. on the meninx, peritoneum and a few other places. On the meninx covering the dorsal and lateral sides of the optic and olfactory lobes and cerebellum are scattered conspicuous melanophores, of which those fringing the lateral rims are particularly large and seen througth the transparent cranium enclosing the brain; the peritoneum is spotted with numerous melanophores which are partly seen through the translucent muscular tissue of the belly; and the midventral pigment bar just behind the anal fin has become very thick. The melanophores on the antero-dorsal surface of the snout are now distinctly arranged along the lateral sides of the mesethmoid and on the outer surface of the supraocular canal, and extend the distribution posteriorly.

The specimen illustrated in Fig. 8 is 26.9 in standard length; snout 2.58; eye 2.08 ; head 8.01 ; prepectoral 8.08 ; predorsal 13.5 ; preventral 14.8 ; preanal 22.1 ; snout to the base of adipose fin (=preadipose length) 23.1 ; preanus 21.2 ; postanus 5.72; greatest body depth 3.58 ; all in $\mathrm{mm}$. Number of fin-rays: dorsal 11; anal 10 ; pectoral 19 ; ventral 12 . The myomeres $38+12=50$.

Early Young Stage (Pl. XIV, Fig. 9)

The snout is furthermore protruded, and so is the lower jaw slightly beyond the tip of the upper jaw; the dorsal profile of the head is now descending nearly straightly from the frontal region to the snout tip, being interrupted by the dorsal rim of the nostril. This general outline of the head resembles well that of the adult. The body is deepest between the bases of the pectoral and the dorsal fin. No tooth on the premaxillary; the comb-like larval teeth on the dentary show a trend towards degeneration from both the anterior and posterior ends, being replaced by several stouter teeth in the posterior part of the edge. The vomerine and tongue teeth have become stouter, their number and arrangement on respective sites approach those of 
the adult. Further reduction of pigmentation is achieved: the flecks along the lower lateral edge of the lower jaw are now faint and those along the lower edge of the opercular flap are represented by very minute dots, while the transverse stripes on each side of the body are receded almost to the dorsal half of the body excep for the last one which covers the base of the caudal fin. The melanophores on the inner surface of the opercle have almost disappeared. On the other hand, the pigment cells on the meninx covering the brain and those at the outer dorsal corner of the opercle have become considerably denser.

The specimen shown in Fig. 9 is 36.5 in standard length; snout 3.29 ; eye 3.01 ; head 10.6 ; prepectoral 10.3 ; predorsal 17.6 ; preventral 19.6 ; preanal 29.4 ; preadipose 30.3 ; preanus 28.5 ; postanus 8.01 ; greatest body depth 5.01 ; all in $\mathrm{mm}$. Number of fin-rays: dorsal 11 ; anal 12 ; pectoral 19 ; ventral 12 . The myomeres $39+\mathbf{1 1}=50$.

\section{Advanced Young Stage (Pl. XIV, Fig. 10)}

The head is quite elongated, gently tapering to the anterior end; its dorsal surface is almost flat from the nape to the tip of the snout; and the lower jaw is distinctly protruded beyond the upper jaw; thus, the profile is quite the same as that of the adult. The body is deepest immediately behind the head. The adipose fin now takes the ultimate, compact and translucent form as seen in the adult, and the pectoral fin is shifted to the eventual situation near the ventro-lateral contour of the trunk and laid nearly horizontally. The comb-like larval teeth on the dentary are totally lost and the adult teeth are arranged along the posterior half of the upper edge of the dentary. The pigment blotches on each side of the body are much reduced to dusky ones arranged in a series well above the lateral line. The pigments on the lower edge of the opercular flap have completely disappeared, and those on the lower edge of the lower jaw are quite indistinct. Meanwhile, the melanophores on the brain meninx and around the mesethmoid, supraocular canals and their adjoining regions on the antero-dorsal part of the snout and those on the outer dorsal corner of the opercle have become further denser; in addition, some conspicuous pigment flecks, given rise to by the first pigment blotch on the body side having migrated anteriorly and been reassembled, appear on the nape and in the dorsal corner of the shoulder girdle region. All these pigmentations belong to the adult array.

The specimen illustrated in Fig. 10 is 66.9 in standard length; snout 6.44 ; eye 5.15 ; head 18.5 ; prepectoral 18.9 ; predorsal 31.8 ; preventral 26.2 ; preanal 54.3 ; preadipose 56.5 ; preanus 52.6 ; postanus 14.3 ; greatest body depth 8.30 ; all in $\mathrm{mm}$. Number of fin-rays : dorsal 11 ; anal 12 ; pectoral 19 ; ventral 12. The myomeres $38+11=49$. 
Comparisons with Related Species

The species most closely related to Glossanodon semifasciatus are G. leioglossus (VALENCIENNES) known from the Mediterranean and Canary Islands and G. polli CoHen recorded from the South Atlantic off the West African and the Brazilian coast. The early development of the former was worked out first by Schmidt (1918) and later by SANzo (1931) more precisely, while an adolescent specimen of the latter was depicted by PoLL (1953) under the name Argentina sphyraena.

The egg of $G$. semifasciatus appears to be slightly larger than that of $G$. leioglossus $(1.5-1.6 \mathrm{~mm} \text { against } 1.4-1.5 \mathrm{~mm})^{4)}$, while the oil globule is of the same size $(0.36 \mathrm{~mm})$ in both species. The pigmentation in late embryonic as well as early larval stages is somewhat different between the two species: $G$. semifasciatus has melanophores on the yolk sac in addition to the somatic pigment cells, while the melanophores are limited to the embryonal body in G. leioglossus. The pigmentation in postlarval and later stages differs considerably, too: for instance, eight preanus and three postanus transverse stripes or blotches on each side of the body in G. semifasciatus against seven and two in G. leioglossus, and the stripes are gradually reduced to be limited in the dorsal half of the lateral side of body toward the end of metamorphic stage in G. semifasciatus whereas they remain almost unchanged up to the young stage in G. leioglossus (SANzo 1931 gives an illustration of a $42.4-\mathrm{mm}$ young of $G$. leioglossus, which shows nine conspicuous transverse stripes on the side of body and an additional one across the caudal fin). The presence of buried pigments in the range from the snout to the postero-inferior corner of the opercle is a feature common to the postlarvae of both species.

An 83-mm adolescent specimen of G. polli, illustrated by PolL (1953), shows clearly nine conspicuous transverse stripes on the lateral side of body, seven in the preanus ${ }^{5}$ and two in the postanus region; it is surprising that larval pigmentation is sustained still by such a large young in this species. As far as the pigmentation in the young stage, its pattern and persistency, is concerned, this recently found species (COHEN 1958) resembles its Atlantic ally rather than its Pacific cognate.

\section{REFERENCES}

Aboussouan, A. 1964. Contribution à l'étude des oeufs et larves pélagiques des poissons téléostéens dans le Golfe de Marseille. Rec. Trav. Stat. End., no. 32, fasc. 48, pp. 87-173. Cohen, D. M. 1958. A revision of the fishes of the subfamily Argentininae. Bull. Florida

4) The egg diameter of G. leioglossus is quoted from SAnzo's (1931) paper, in which the fresh live eggs are treated.

5) The seventh stripe is shown just behind the vent opening in PoLI's (1953) figure; ontogenetically speaking, however, this is undoubtedly the last preanus stripe. 
State Mus., vol. 3, pp. 93-172.

Ehrenbaum, E. 1909. Eier und Larven von Fischen, Teil II. Nordisches Plankton, Lief. 10, pp. $217-413$.

FAGE, L. 1910. Recherches sur les stades pélagiques de quelques Téléostéens de la mer de Nice (Parages de Monaco) et du Golfe du Lion. Ann. Inst. Océanogr., vol. 1, fasc. 7, 53 pp., $1 \mathrm{pl}$.

HANyu, I. 1956. On the age and growth of argentine (Argentina semifasciata KisHINouye). Bull. Japanese Soc. Sci. Fish., vol. 21, pp. 991-999. (In Japanese).

JACOBSHAGEN, E. 1937. Mittel und Enddarm (Rumpfdarm). In: BöLK, L. et al. Handbuch der vergleichenden Anatomie der Wirbeltiere, Bd. III. Berlin u. Vienna, pp. 563-724.

KamoHARA, T. 1952. Revised descriptions of the offshore bottom-fishes of Prov. Tosa, Shikoku, Japan. Repts. Kochi Univ., Nat. Sci., no. 3, 122 pp.

Karlovac, J. 1949. Premières découvertes de post-larves de la famille Argentinidae, en Adriatique. Acta Adriatica, vol. 4, no. 4, 16 pp., 2 charts.

MATSUbaRA, K. 1943. Ichthyological annotations from the depth of the sea of Japan, I-VIII. J. Sigenkagaku Kenkyusho, vol. 1, pp. 37-81, 1 pl.

OchlaI, A. 1952a. Ecological studies on a clupeoid fish Argentina semifasciata KISHINoUye, I. The relation between the body length and the body weight. Bull. Japanese Soc. Sci. Fish., vol. 18, pp. 139-146. (In Japanese).

- 1952b. Ditto, II. The equilibrium constant between the body length and the body weight. Res. Population Ecol., Kyoto, no. 1, pp. 143-151. (In Japanese).

1954. Ditto, III. Gonad. Bull. Japanese Soc. Sci. Fish., vol. 19, pp. 968-972. (In Japanese).

Pold, M. 1953. Poissons, III. Téléostéens Malacoptérygiens. Expéd. Océanogr. Belge dans les eaux côtières Africaines de l'Atlantique Sud (1948-1949). Résultats Scientifiques, vol. 4, fasc. 2,258 pp., 8 pls.

Sanzo, L. 1931. Uova, larve e stadi giovanili di Teleostei : Salmonoidei. Fauna e Flora del Golfo di Napoli, monogr. 38, pp. 21-42, pls. II-III.

Schmidt, E. J. 1906. On the larval and post-larval development of the argentines (Argentina silus (ASCAN.) and Argentina sphyraena LINNÉ) with some notes on Mallotus villosus (O.F. Mǘller). Meddelelser Komm. Havunders $\phi$ g., Ser. Fiskeri, vol. 2, no. 4, 29 pp, 2 pls.

1918. Argentinidae, Microstomidae, Opisthoproctidae. Mediterranean Odontostomidae. Rept. Danish Oceanogr. Exped., 1908-1910, to the Mediterranean and adjacent seas, vol. II Biol, art. 5, 40 pp.

WATANABE, T. 1956. [Fisheries biology of commercially important bottom animals in the Japan Sea: Argentina semifasciata KISHINouye]. Bull. Japan Sea Reg. Fish. Res. Lab., no. 4, pp. 159-182. (In Japanese). 


\section{EXPLANATION OF PLATES XIII-XIV}

\section{Development of Glossanodon semifasciatus (KISHINOUYE)}

1. Blastula stage.

2. Early tail-bud stage.

3. Late tail stage.

4. Early larval stage.

5. Advanced larval stage.

The scale indicates $1 \mathrm{~mm}$ for Figs. 1 to 5 .

The segmentation of yolk is shown only in part in Figs. 1 to 4

6. Postlarval stage.

7. Early metamorphic stage.

The scale indicates $5 \mathrm{~mm}$ for Figs. 6 and 7 .

8. Late metamorphic stage.

9. Early young stage.

10. Advanced young stage.

The scale indicates $10 \mathrm{~mm}$ for Figs. 8 to 10 
Publ. Seto Mar. Biol. Lab., XIII (5), 1966

PLATE XIII
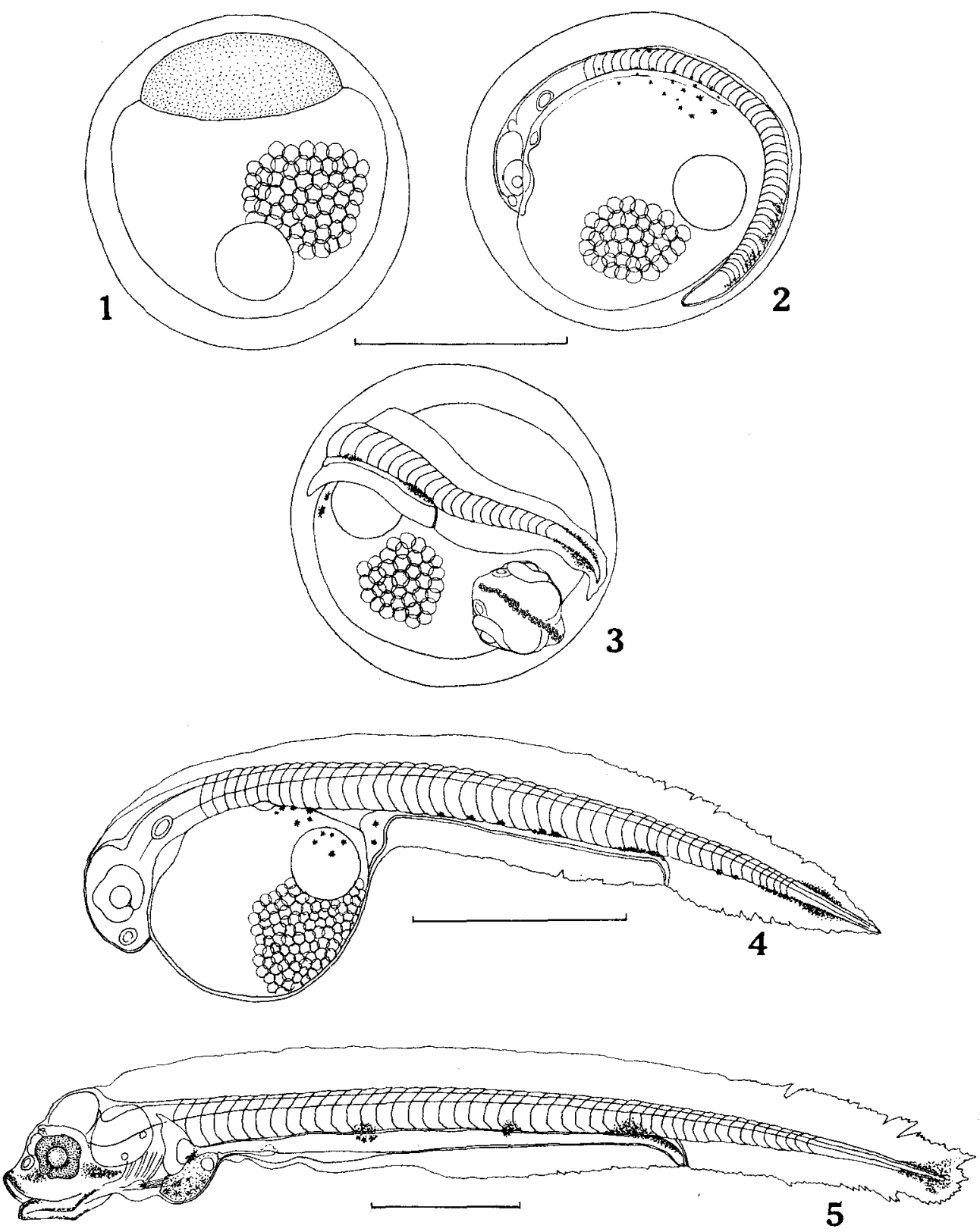

S. NISHIMURA : Early Life History of Glossanodon semifasciatus Part I 
Publ. Seto Mar. Biol. Lab., XIII (5), 1966
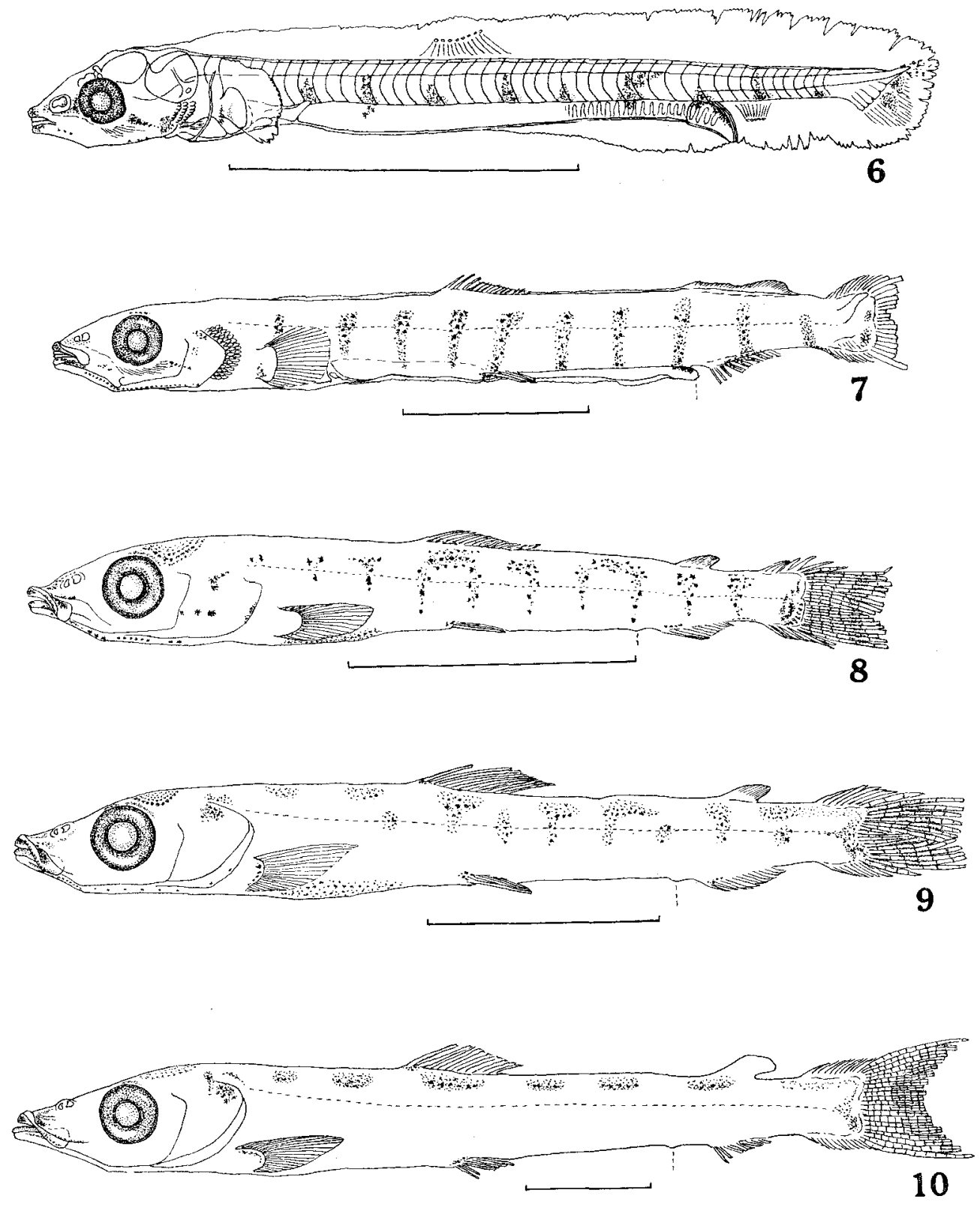

S. Nishimura: Early Life History of Glossanodon semifasciatus Part I 